\title{
Assessment of Hospital Information System Quality in Multi Specialty Hospitals
}

\author{
G. V. R. K. Acharyulu
}

\begin{abstract}
The rapid advance of information technology in health settings has accentuated the importance of addressing the shortcomings of current health information system practices. Hospital Information Systems (HIS) play a significant role in providing quality healthcare services. However, HIS lag behind their industrial counterparts in providing quality (i.e., timely, accurate, complete) information and have been the target of many criticisms for alleged shortcomings. The aim of this research is to identify the requirements for HIS to assist in providing quality healthcare service. To this end, questionnaires were designed to assess the level of satisfaction of different HIS users. In addition, this research introduces the concept of loss function and relates it to repercussions of HIS customer dissatisfaction.
\end{abstract}

Index Terms-Information System (IS), technology, Hospital Information System (HIS), customer satisfaction.

\section{INTRODUCTION}

Hospital Information System can be defined as a massive, integrated system that support the comprehensive information requirements of hospitals, including patient, clinical, ancillary and financial management [1] [2] [3] [4]. Hospitals are extremely complex institutions with large departments and units coordinate care for patients. Hospitals are becoming more reliant on the ability of hospital information system (HIS) to assist in the diagnosis, management and education for better and improved services and practices [5].

The term "quality" of information systems has been categorized by six major dimensions of IS success [6]: System Quality, Information Quality, Use, User Satisfaction, Individual Impact and Organizational Impact. But HIS now incorporate a significant service component which should be added to the six dimensions. Indeed, HIS customers expect the HIS department to assist them with a myriad of tasks, such as hardware and software selection, installation, problem resolution, integration with other networks, system modifications or development, education, conversion of data to information meaningful for decision making, etc. [7]. Information systems applications have contributed to better health service management and delivery of care by creating an environment conducive to increased access and quality of patient care and by supporting the knowledge base required for clinical and administrative decision making.

There has been a major paradigm shift in healthcare information processing, corresponding to changes in the goals of the organization. The traditional emphasis on data

Manuscript received May 12, 2012; revised June 19, 2012.

G. V. R. K. Acharyulu is with the School of Management Studies, University of Hyderabad, India (e-mail: acharyulu_gvrk@yahoo.com). has now given way to emphasis on information. Central control has now evolved to empowerment. Healthcare organizations are now much more concerned with each other and how they can exchange services, and necessarily patient information. This has forced information systems to leave the traditional

Healthcare institutions' physical boundaries. Now, more than ever, healthcare enterprises wield HIS to provide strategic, connected information to reduce costs, improve patient care, and increase service levels to their customers.

With the changes occurring in the context of the health sector reform processes information systems must have the ability to:

- Capture and deliver data at the point of service

- Support concurrent and multi-centric clinical and administrative information utilization and exchange

- Support intensive data manipulation

- Provide facilities to support synchronous, as opposed to retrospective, decision making

Health information systems (HIS) comprise the entire infrastructure, organisation, workforce and components for the collection, processing, storage, transmission, display, dissemination and disposition of information in the healthcare industry1. In many clinical and hospitals settings, HIS tend to consist of enormous silos of paper-based or electronic data that are fragmented or of poor quality, exposing systems to risk of infraction. Rapid advances in information technology (IT) enablers and mobile devices such as personal digital assistants (PDA), or combination personal computer (PC)/phone devices, has done little to diminish these threats.

Hospital Information System (HIS) has evolved as an integration system of order entry systems, an administrative system, and departmental subsystems within a hospital. It has become more and more necessary for every health care staff in a hospital to use a computer terminal at almost every day's works. Under this circumstances, HIS is expected to provide the staffs with various, world-wide information for decision making and better communication environment which can be used just on the computer terminals for everyday's works. Furthermore, tele-communication between a central hospital and a satellite clinic/hospital has become more and more necessary especially when a physician consult with domain experts in other hospitals concerning his/her patients' care.

Hospital information systems (HIS) are just one instance of health information systems, with a hospital as health care environment. A HIS is a comprehensive and integrated information system designed to store, manipulate, retrieve information of the administrative and clinical aspects [8]. 


\section{OBJECTIVES}

The objective of the study is to assess customer satisfaction of HIS to identify the status of information quality in hospitals and develop a integrated information system model by taking inputs from users of HIS for quality improvement.

\section{Methodology}

The research instrument was a questionnaire adapted from Barley and Pearson (1983) and Ribière et al. (1999) (cited in [9]) but has been modified to suit the purpose of this study. HIS customers can be identified as internal or external. Internal customers are Doctors, Nurses, Laboratory technologists, Pharmacists, Quality department, and others within a healthcare facility that interact with the essential processes. External customers are: Patients, Patients' families, Insurance Providers, Suppliers, Health Services Researchers, etc. This research study focuses on internal HIS users (or customers) only

The research design is qualitative and consists of three leading multispecialty corporate hospitals (above 500 bedded) in Hyderabad. The names of the corporate hospitals are masked to avoid inter conflict of opinion among the hospitals in the competitive environment. Population consists of Doctors, Nurses, Administrative staff and other users.

The questionnaires were distributed to 180 HIS users from three different hospitals 60 from each hospital that uses the same HIS system. These respondents were selected through purposive sampling. The assessment of variables measured using Likert's five point scale viz. 1.Stongly Disagree 2. Disagree 3. Neither Agree nor Disagree 4. Agree 5. Strongly Agree.

\section{RESUlts AND ANALYSIS}

\section{A. Descriptive Statistics}

Table 1 shows the descriptive statistics of the sample. The customers have given higher average score i.e. 4.16 for the assessment variable no.11: the present information system needs modifications and improvement for efficient and effective patient care. Similarly, there is agreement among users that HIS will improve quality of decision making i.e. the average score is 4.11 for the assessment variable no. 2 . The variables nearer to agreement are 8 and 10 indicate that information system can reduce waiting time in the care process and information delay was happened due to network connectivity. The users are disagreeing on the ability to communicate and exchange data among departments and some customization is required to the Information System.

\begin{tabular}{|c|c|c|c|}
\hline S. No & Assessment Variable & Mean & $\begin{array}{l}\text { Std. } \\
\text { deviation }\end{array}$ \\
\hline 1 & $\begin{array}{l}\text { Information System provides } \\
\text { sufficient, accurate, understandable } \\
\text { and timely information }\end{array}$ & 3.03 & 1.160 \\
\hline 2 & $\begin{array}{l}\text { HIS improve the quality of decisions } \\
\text { by making information readily } \\
\text { available }\end{array}$ & 4.11 & .957 \\
\hline 3 & $\begin{array}{l}\text { The output is presented in a useful } \\
\text { format in a well designed layout and } \\
\text { graphics }\end{array}$ & 2.70 & .978 \\
\hline 4 & $\begin{array}{l}\text { The Information System has ability to } \\
\text { offer a chance to reverse and correct a } \\
\text { mistake }\end{array}$ & 3.06 & 1.195 \\
\hline 5 & $\begin{array}{l}\text { The Information System is easy to use } \\
\text { in terms of menus and customization }\end{array}$ & 2.49 & 1.187 \\
\hline 6 & $\begin{array}{l}\text { The Information System has ability to } \\
\text { communicate and exchange data } \\
\text { among departments }\end{array}$ & 2.12 & .744 \\
\hline 7 & $\begin{array}{l}\text { The Information System provides } \\
\text { complete and secured information }\end{array}$ & 2.99 & .609 \\
\hline 8 & $\begin{array}{l}\text { The Information System can reduce } \\
\text { waiting time }\end{array}$ & 3.79 & .971 \\
\hline 9 & $\begin{array}{l}\text { Delayed from or prevented using the } \\
\text { Information System due to password } \\
\text { problems }\end{array}$ & 3.08 & .919 \\
\hline 10 & $\begin{array}{l}\text { Delayed from or prevented using the } \\
\text { Information System because network } \\
\text { connectivity }\end{array}$ & 3.80 & 1.103 \\
\hline 11 & $\begin{array}{l}\text { Present information system needs } \\
\text { modification or improvement for } \\
\text { efficient and effective patient care. }\end{array}$ & 4.16 & .750 \\
\hline 12 & $\begin{array}{l}\text { Database access problem when } \\
\text { attending patient-related work }\end{array}$ & 3.41 & .576 \\
\hline
\end{tabular}

\section{B. Inferential Statistics}

Data gathered was not normally distributed for all type of inferential analysis. This is based on the Shapiro and Wilk analysis. As the p-value is less than 0.05 , the distribution is not normal. Thus Kruskal-Wallis test was used for the nonparametric analysis. The Cronbach's Alpha is 0.607 for the data collected for 12 items which indicates the reliability if data. The significance results were shown in Table 2.

- There is statistically significant difference in 'HIS improve the quality of decisions by making information readily available' score across three groups as the sigvalue was 0.009 and less than alpha level 0.05 , and an inspection the mean ranks of Doctors had the highest agreement followed with Nurses, Administrative and 'others'.

- There is statistically significant difference in 'The output is presented in a useful format in a well designed layout and graphics' score across three groups as the sig-value was 0.015 and less than alpha level 0.05, and an inspection the mean ranks of Administrative and 'others' had the highest agreement followed with Nurses, and Doctors. 
TABLE II: KRUSKAL-WALLIS TEST RESULTS (DF $=2$, ALFA $=0.05)$

\begin{tabular}{|c|c|c|c|c|}
\hline Assessment Variable & category & $\mathrm{N}$ & $\begin{array}{l}\text { Mean } \\
\text { Rank }\end{array}$ & $\begin{array}{l}\text { Chi-square } \\
\text { Asymp } \\
\text { significance }\end{array}$ \\
\hline \multirow{4}{*}{$\begin{array}{l}\text { Information System } \\
\text { provides sufficient, } \\
\text { accurate, } \\
\text { understandable and } \\
\text { timely information }\end{array}$} & Doctors & 60 & 89.78 & \\
\hline & Nurses & 60 & 88.90 & 0.902 \\
\hline & $\begin{array}{l}\text { Administrative and } \\
\text { others }\end{array}$ & 60 & 92.83 & \\
\hline & Total & 180 & & \\
\hline \multirow{4}{*}{$\begin{array}{l}\text { HIS improve the } \\
\text { quality of decisions by } \\
\text { making information } \\
\text { readily available }\end{array}$} & Doctors & 60 & 105.00 & \\
\hline & Nurses & 60 & 89.21 & 0.009 \\
\hline & $\begin{array}{l}\text { Administrative and } \\
\text { others }\end{array}$ & 60 & 77.29 & \\
\hline & Total & 180 & & \\
\hline \multirow{4}{*}{$\begin{array}{l}\text { The output is } \\
\text { presented in a useful } \\
\text { format in a well } \\
\text { designed layout and } \\
\text { graphics }\end{array}$} & Doctors & 60 & 75.62 & \\
\hline & Nurses & 60 & 95.49 & \\
\hline & $\begin{array}{l}\text { Administrative and } \\
\text { others }\end{array}$ & 60 & 100.39 & 0.015 \\
\hline & Total & 180 & & \\
\hline \multirow{4}{*}{$\begin{array}{l}\text { The Information } \\
\text { System has ability to } \\
\text { offer a chance to } \\
\text { reverse and correct a } \\
\text { mistake }\end{array}$} & Doctors & 60 & 81.03 & \\
\hline & Nurses & 60 & 94.33 & 0.200 \\
\hline & $\begin{array}{l}\text { Administrative and } \\
\text { others }\end{array}$ & 60 & 96.13 & \\
\hline & Total & 180 & & \\
\hline \multirow{4}{*}{$\begin{array}{l}\text { The Information } \\
\text { System is easy to use } \\
\text { in terms of menus and } \\
\text { customization }\end{array}$} & Doctors & 60 & 77.28 & \\
\hline & Nurses & 60 & 94.17 & 0.035 \\
\hline & $\begin{array}{l}\text { Administrative and } \\
\text { others }\end{array}$ & 60 & 100.05 & \\
\hline & Total & 180 & & \\
\hline \multirow{4}{*}{$\begin{array}{l}\text { The Information } \\
\text { System has ability to } \\
\text { communicate and } \\
\text { exchange data among } \\
\text { departments }\end{array}$} & Doctors & 60 & 73.75 & \\
\hline & Nurses & 60 & 88.10 & \\
\hline & $\begin{array}{l}\text { Administrative and } \\
\text { others }\end{array}$ & 60 & 109.65 & 0.018 \\
\hline & Total & 180 & & \\
\hline \multirow{4}{*}{$\begin{array}{l}\text { The Information } \\
\text { System provides } \\
\text { complete and secured } \\
\text { information }\end{array}$} & Doctors & 60 & 92.81 & \\
\hline & Nurses & 60 & 85.31 & 0.045 \\
\hline & $\begin{array}{l}\text { Administrative and } \\
\text { others }\end{array}$ & 60 & 95.38 & \\
\hline & Total & 180 & & \\
\hline \multirow{4}{*}{$\begin{array}{l}\text { The Information } \\
\text { System can reduce } \\
\text { waiting time }\end{array}$} & Doctors & 60 & 79.05 & \\
\hline & Nurses & 60 & 91.20 & 0.049 \\
\hline & $\begin{array}{l}\text { Administrative and } \\
\text { others }\end{array}$ & 60 & 101.25 & \\
\hline & Total & 180 & & \\
\hline \multirow{4}{*}{$\begin{array}{l}\text { Delayed from or } \\
\text { prevented using the } \\
\text { Information System } \\
\text { due to password } \\
\text { problems }\end{array}$} & Doctors & 60 & 90.40 & \\
\hline & Nurses & 60 & 91.51 & 0.977 \\
\hline & $\begin{array}{l}\text { Administrative and } \\
\text { others }\end{array}$ & 60 & 89.59 & \\
\hline & Total & 180 & & \\
\hline \multirow{4}{*}{$\begin{array}{l}\text { Delayed from or } \\
\text { prevented using the } \\
\text { Information System } \\
\text { because network } \\
\text { connectivity }\end{array}$} & Doctors & 60 & 79.19 & \\
\hline & Nurses & 60 & 92.28 & 0.003 \\
\hline & $\begin{array}{l}\text { Administrative and } \\
\text { others }\end{array}$ & 60 & 100.03 & \\
\hline & Total & 180 & & \\
\hline \multirow{2}{*}{$\begin{array}{l}\text { Present information } \\
\text { system needs }\end{array}$} & Doctors & 60 & 77.43 & \\
\hline & Nurses & 60 & 98.28 & 0.022 \\
\hline
\end{tabular}

\begin{tabular}{|l|l|l|l|l|}
\hline \multirow{2}{*}{$\begin{array}{l}\text { modification or } \\
\text { improvement for } \\
\text { efficient and effective } \\
\text { patient care. }\end{array}$} & $\begin{array}{l}\text { Administrative and } \\
\text { others }\end{array}$ & 60 & 95.79 & \\
\cline { 2 - 5 } & Total & 180 & & \\
\hline $\begin{array}{l}\text { Database access } \\
\text { problem when } \\
\text { attending patient- } \\
\text { related work }\end{array}$ & Doctors & 60 & 89.35 & \\
\cline { 2 - 6 } & $\begin{array}{l}\text { Nurses } \\
\text { others }\end{array}$ & 60 & 94.10 & 0.747 \\
\cline { 2 - 6 } & Total & 60 & 88.05 & \\
\hline
\end{tabular}

- There is statistically significant difference in 'The Information System is easy to use in terms of menus and customization' score across three groups as the sigvalue was 0.035 and less than alpha level 0.05 , and an inspection the mean ranks of Administrative and 'others' had the highest agreement followed with Nurses, and Doctors.

- There is statistically significant difference in 'The Information System has ability to communicate and exchange data among departments' score across three groups as the sig-value was 0.018 and less than alpha level 0.05, and an inspection the mean ranks of Administrative and 'others' had the highest agreement followed with Nurses, and Doctors.

- There is statistically significant difference in 'The Information System provides complete and secured information' score across three groups as the sig-value was 0.045 and less than alpha level 0.05 , and an inspection the mean ranks of Administrative and 'others' had the highest agreement followed with Doctors and Nurses.

- There is statistically significant difference in 'The Information System can reduce waiting time' score across three groups as the sig-value was 0.049 and less than alpha level 0.05, and an inspection the mean ranks of Administrative and 'others' had the highest agreement followed with Nurses and Doctors.

- There is statistically significant difference in 'Delayed from or prevented using the Information System because network connectivity' score across three groups as the sig-value was 0.003 and less than alpha level 0.05, and an inspection the mean ranks of Administrative and 'others' had the highest agreement followed with Nurses and Doctors.

- There is statistically significant difference in 'Present information system needs modification or improvement for efficient and effective patient care.' score across three groups as the sig-value was 0.022 and less than alpha level 0.05 , and an inspection the mean ranks of Nurses had the highest agreement followed with Administrative and 'others' and Doctors

\section{CHALLENGES FOR HEALTHCARE INFORMATION SYSTEMS}

New requirements and technological advances occurring in healthcare, information systems, and information technology have influenced the evolving role of healthcare information systems and related technology [10]. Relevant aspects that took place in the evolution of systems and technology in order to appropriately support healthcare 
organizations are:

- $\quad$ The diverse organizational healthcare environment of information systems, which need to be adapted to multiple types of healthcare organizations.

- Dynamic changes in the required role of information systems, following changes in the role and dynamics of all levels of healthcare delivery and management.

- The need for integration of information systems within healthcare organizations, which are also organized as networks.

- Technological advances in systems structure and communications, facilitating the implementation of integrated healthcare networks.

\section{INTEGRATED MODEL OF A HOSPITAL INFORMATION SYSTEM.}

Health care industry is one of the most information intensive and technologically advanced in our society. Thus, the information should be accessible easily, timely, complete, accurate, reliable and relevant information in making important strategic or patient care decisions. Figure 1.1 shows the integration of business process viz. Administration\& Registration, Clinical System, Pharmacy, Electronic Medical Records, Radiology, Laboratory, Accounting and Nursing [11]. To be more precise, the entire hospital system that is being practiced with the manual system has to be completely transformed into electronic by using the latest information technology.

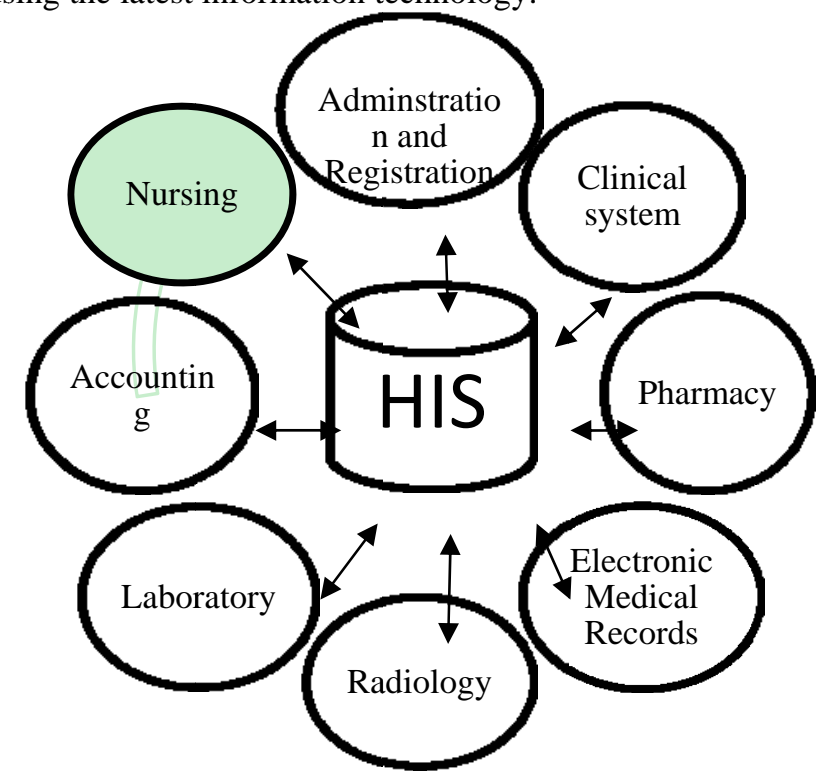

Fig.1. HIS integration model.

\section{CONCLUSION}

From admission to diagnostic and medical support services, the modern healthcare centers rely on wide range of software applications. Proper implementation of HIS modules will definitely lead to improved quality of patient care, communications, productivity and reduced costs, chances of errors. To track patient records, Electronic Medical Records (EMR) has emerged for improving quality of healthcare delivery. In the 21st century, patients will be able to choose the hospital that best meets their needs and satisfies their high standards for medical care requirements.

Hospitals must therefore be prepared to offer medical services tailored to patients' needs. It is also essential for the hospital management to conduct the assessment of HIS regularly by internal customers for incorporating continuous technology innovations and design requirements to satisfy external customers through seamless integration of HIS across all the departments in the hospital.

\section{REFERENCES}

[1] M. M. Yusof, A. Papazafeiropoulou, R. J. Paul, and K. Stergioulas, "Investigating evaluation frameworks for health information systems," International Journal of Medical Informatics, vol. 77, pp. 377-385, 2008.

[2] L. Roussel, R. C. Swansburg, and R. J. Swanburg, "Management and Leadership for Nurse Administrators," Contributor Russell C.Swansburg, Richard J Swansburg. Jones and Bartlett Publisher, 2005.

[3] R. Haux, E. Ammenwerth, and A. Buchauer (Ed). The Requirements Index for Information Processing in Hospitals. Version 1.0b.Germany: Inattitut für Medizinische Biometrie und Informatik (imGi). Supported by the Deutschungsgemeinschaft (DFG), Adopted by the DFG's Computing Facilities, 2001.

[4] M. F. Collen, “A vision of health care and informatics in 2008,” $J$ Am Med Inform Assoc. 1999 Jan- Feb, vol. 6, no.1, pp. 1-5, 1999.

[5] J. Adler-Milstein, and D. W. Bates, "Paperless healthcare: Progress and challenges of an IT-enabled healthcare system," Business Horizons, vol. 53, no 2, 2010.

[6] D. William H.- McLean Ephraim R. - "Information system success : The quest for the dependant variable," Information Systems Research, March, vol. 3, no. 1, 1992.

[7] P. Leyland F. - Watson Richard T. - Kavan C. Bruce - "Service quality: A measure of information systems effectiveness," - MIS Quarterly, June, vol. 19, no. 2, pp.173-188, 1995.

[8] Y. A. Hayajneh, W. A. Hayajneh, I. I. Matalka, H. Z. Jaradat, Z. Q. Bashabsheh, and M. S. Alyahya, (2006). [Online]. Available: http://hayajneh.startlogic.com/research/Extent_of_Use_.pdf

[9] B. J. E. - Pearson Sammy W, "Development of a tool for measuring and analyzing user satisfaction,” Management Science, May, vol. 29, no. 5, p530-545, 1983.

[10] T. Joseph K. H, Health Management Information Systems, ASPEN Publisher, Inc. 1995, ISBN: 0-8342-0613-7

[11] A. James G., "Clearing the Way for Physicians' Use of Clinical Information Systems," Communication of the ACM, August, vol 40, no. 8, pp.83-90, 1997.

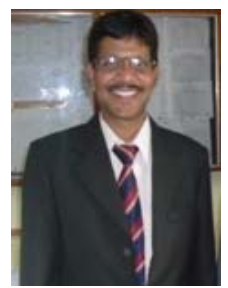

Dr. G. V. R. K. Acharyulu is Reader at the School of Management Studies, University of Hyderabad, India and coordinating MBA (Healthcare \& Hospital Management) program. His current research areas include Operations \& Supply Chain Management, Modeling and Healthcare Management. He has been teaching Hospital Administration, Operations and Supply Chain Management. He has published several research papers in National and International Journals in the area of Operations, Supply Chain and Healthcare. He has also authored books viz., Research Methodology \& Statistical Tools, Marketing Research, Supply Chain Management, Strategic Quality Management, Pharmacy Administration and Supply Chain Management in Healthcare Industry. 